Southern Methodist University

SMU Scholar

Faculty Journal Articles and Book Chapters

Faculty Scholarship

1990

\title{
Scots Law in Post-Revolutionary and Nineteenth-Century America: The Neglected Jurisprudence
}

C. Paul Rogers III

Southern Methodist University, Dedman School of Law

\section{Recommended Citation}

C. Paul III Rogers, Scots Law in Post-Revolutionary and Nineteenth-Century America: The Neglected Jurisprudence, 8 Law \& Hist. Rev. 205 (1990)

This document is brought to you for free and open access by the Faculty Scholarship at SMU Scholar. It has been accepted for inclusion in Faculty Journal Articles and Book Chapters by an authorized administrator of SMU Scholar. For more information, please visit http://digitalrepository.smu.edu. 


\title{
Scots Law in Post-Revolutionary and Nineteenth-Century America: The Neglected Jurisprudence
}

\author{
C. PAUL ROGERS III
}

Little scholarly attention has been paid to the role of Scots law in the development of the post-Revolutionary law and legal system of the United States. This neglect stems largely from the fact that Scots law has had little apparent permanent influence on American law. However, during the "formative era of American law" from the Revolution to the Civil War, ${ }^{1}$ a notable effort to introduce America to civil law concepts took place. ${ }^{2}$ Furthermore, the impact of the Scottish enlightenment on the fledgling United States in higher education, philosophy, and medicine is well documented. ${ }^{3}$ Scottish Enlightenment thought arguably had a significant impact on the Declaration of Independence, ${ }^{4}$ which was signed by at least two native-born Scots and an American who was a graduate of the University of Edinburgh. ${ }^{5}$

David Hume's political essays on freedom and governance of large areas are thought to have been influential in framing the Constitution. ${ }^{6}$ Indeed, James Wilson, one of the two principal draftsmen of the Constitution along with James Madison, ${ }^{7}$ was a native-born Scot who was educated at St. Andrews. He was apparently greatly influenced by the work of such eminent Scots as Thomas Reid, Francis Hutcheson, and Lord Kames as well as Hume. ${ }^{8}$ Wilson was subsequently appointed to the Supreme Court and, concurrently, to a law professorship at the College of Philadelphia (later to become the University of Pennsylvania), where he delivered the first lectures on law in the new nation.'

The widespread post-Revolutionary view was that America should develop a uniquely American jurisprudence, which would be eclectic

C. Paul Rogers III is dean and professor at Southern Methodist University School of Law.

Law and History Review Fall 1990, Vol. 8, No. 2

(C) 1990 by the Board of Trustees of the University of Illinois 
rather than derived solely from the English common law. ${ }^{10}$ For example, Wilson, in his inaugural lecture, argued for the establishment "of a separate, an unbiased, and an independent law education" for the United States. " After the Revolution and culminating with the War of 1812, anti-English feeling or Anglophobia was rampant and resulted in the passage of a number of state statutes prohibiting the use of English legal precedents in their judicial proceedings. For example, a 1799 New Jersey statute prohibited the receipt of reading in court of any British decision rendered after July 4, 1776, while a 1807 Kentucky statute declared that "records and books containing adjudged cases in ... Great Britain ... since the fourth day of July, 1776, shall not be read or considered as authority in ... the courts of this Commonwealth."12

Civil law presented the only real alternative to wholesale adoption of the English common law system. While France was held in high esteem in the United States due to its support and aid of American independence, few American lawyers had any knowledge or understanding of French or civilian legal systems or the ability to read French, Latin, or German. ${ }^{13}$ Scots law, a civil law system and thus an alternative to the common law, ${ }^{14}$ could have provided another viable alternative, or arguably, should have been an influential source for American law, if Americans had undertaken a rational choice of laws.

Scotland was formally a part of Great Britain as a result of the Union of 1707 and a number of its intelligentsia were outspoken in their opposition to the separatist ambitions of the American colonists. ${ }^{15}$ Others, such as David Hume and Adam Smith, supported the colonists from early on. ${ }^{16}$ Scottish immigrants were also apparently split in their allegiance, although the majority were probably Tories or neutrals. ${ }^{17}$ Certainly some of the most prominent Scots in America, such as Witherspoon and Wilson, were patriots. ${ }^{18}$

Thus, while mainstream public opinion in America may have viewed the Scottish-American population as principally loyalist, probably creating some antipathy toward Scotland, anti-English feeling was much more pronounced. No ready explanation for the apparent minimal influence of Scots law, particularly as opposed to English law, lies there. Scots law, with its civil law underpinnings and its closer relationship to French and other Continental legal systems, should have presented a viable alternative to the common law. Language was not a barrier as with the Continental systems and Scottish institutional works were available or attainable. ${ }^{19}$

Further, the number of people of Scots birth or descent in the United States was not insignificant; in 1790 , they numbered about 260,000 , 
representing about 8.3 percent of the population. ${ }^{20}$ In Georgia and North and South Carolina, Scots accounted for about 15 percent of the population. ${ }^{21}$ As mentioned previously, some Scots were prominent lawyers and politicians, and the Scottish Enlightenment was quite influential in many areas of American cultural and intellectual life. Given these facts, Scots law appears not to have had a significant impact on American law, even though America was a new country with the need to develop a legal system.

To what degree did Scots law influence early American law and why was this influence not greater? The answer lies within development of Scottish law and the American pre- and post-Revolutionary legal climate, but first it is necessary to discuss the tangible evidence of Scottish and post-Revolutionary American legal involvement.

\section{Evidence of Scots Law in America}

The seventeenth century is especially significant in the development of modern Scots law, due in large measure to the publication of socalled institutional works (treatises) by Scottish jurists such as Stair and Mackenzie. ${ }^{22}$ Institutional works not only gave Scots law form and substance but also came to be authoritative Scottish legal sources ranking just after legislation and judicial precedent. ${ }^{23}$

Interestingly, the works of George Joseph Bell, not those of the more famous Viscount Stair, seem to have been more widely used in the early nineteenth-century United States. Bell was the last Scottish writer to have his work attain institutional status in Scotland. ${ }^{24}$ The institutional works were not widely available in colonial America: ${ }^{25}$ There were more copies in post-Revolutionary America, but no American editions appeared as with Coke's and Blackstone's works. ${ }^{26}$ Bell's works were frequently cited in the first American law treatise, James Kent's Commentaries on American Law, published in 1826. ${ }^{27}$ Joseph Story also made frequent reference to Bell and other Scottish writers such as Erskine and Stair in his treatises. ${ }^{28}$

A brief but mutually solicitous and reverential correspondence between Bell and Story survives. ${ }^{29}$ Story's letter to Bell (written on June 8,1839 , to thank Bell for copies of Bell's most recent works) refers to his then "liberal use of your own excellent Commentaries on Commercial Law." ${ }^{30}$ Story further praises the work: "I have used it constantly in the preparation of all my works upon topics connected with the law of contracts, and especially of commercial law, and I have derived many of the most valuable illustrations from it. I can, therefore, truly 
say that though I have not a personal acquaintance with you, yet I feel that you are among my most familiar friends." 31 Story goes on to express "surprise as well as ... regret" that "Scottish jurisprudence" was not more influential in England, further remarking that "[o]n the subject of international Jurisprudence you have been altogether ahead of them." ${ }^{32}$

Story's letter to Bell next engages in what turns out to be false prophecy: "In the next age I cannot but doubt, but that in England and America the writings of Scottish jurists will be as much consulted and as highly esteemed as are now your authors in the general walks of literature." While this sentiment may, with hindsight, thought to be wishful thinking, it vividly illustrates what might have been.

Bell was more frequently cited in the United States Supreme Court reporters than any other Scottish jurist except Erskine, probably because of the frequent references to his works by Kent and Story. Beginning in $1843,{ }^{33}$ there were twelve Supreme Court and two Ohio Supreme Court citations to Bell ${ }^{34}$ Of the U.S. Supreme Court references, only four were in the Court's opinions, ${ }^{35}$ one was in a dissenting opinion, ${ }^{36}$ and the balance were made by counsel. ${ }^{37}$

There are at least seventeen Supreme Court references to the works of John Erskine, the most frequently cited of the Scots institutional writers. Erskine, a Professor of Scots Law at the University of Edinburgh, preceded Bell and published a work in 1754 entitled The Principles of the Law of Scotland. ${ }^{38}$ His most distinguished work, An Institute of the Law of Scotland, was published posthumously in $1773 .{ }^{39}$ Erskine's work was also frequently cited by Kent and Story, probably again explaining its relative popularity with the American bench and bar. ${ }^{40}$ Of the citations to Erskine, nine appear in the Court's opinions (with one additional citation by the Ohio Supreme Court), ${ }^{41}$ five are attributable to counsel, ${ }^{42}$ and two are in the case appendices. ${ }^{43}$

American judicial citations to other Scots legal scholars are even sparser. For example, there are apparently only three United States Supreme Court and one Ohio Supreme Court references to Stair in the nineteenth century. ${ }^{44}$ Similarly, only three American judicial references can be found to the leading work on Scots criminal law, Commentaries on the Law of Scotland Respecting Crimes written by David Hume, nephew of the famed philosopher of the same name. ${ }^{45}$ The succeeding major work on Scots criminal law, Alison's Principles of the Criminal Law of Scotland (1832), ${ }^{46}$ drew almost no notice in American courts. ${ }^{47}$

Even more remarkable is the scant attention the American judiciary paid to Lord Kames's Principles of Equity. ${ }^{48}$ This work is not strictly 
speaking a legal treatise, but is more theoretical or jurisprudential. It attracted great attention in the United Kingdom and was well known to Story, who disagreed with Kames's view that equity should aid in "correcting, mitigating, or interpreting the law."49 Among the many contributions of the work was the first analysis of private international law from a Scots law perspective. ${ }^{50}$ It was undoubtedly Kames to whom Story referred in his letter to Bell when he wrote, "[O]n the subject of international Jurisprudence you have been altogether ahead of them."s1 Yet, in spite of the significance of Kames's work and his reputation as a leading Enlightenment figure, Principles of Equity is cited in only four American cases in the nineteenth century. ${ }^{52}$

Lord Kames also won renown for his Historical Law Tracts, published in $1758 . .^{53}$ This is a work of comparative legal history with significant sociological and philosophical underpinnings, which investigates the divergence of the Scottish and English legal systems. ${ }^{54}$ It had a significant impact in Britain, on the Continent, and on the thinking of many of the leaders of the fledgling United States. Thomas Jefferson and John Adams owned copies and made copious notes in the margins and introduced major extracts into their own work. ${ }^{5 s}$ However, research has uncovered no American judicial references to it.

While it is perhaps understandable that a broad, non-doctrinal work such as Historical Law Tracts would have little impact on American courts, their failure to refer to a large number of traditional, doctrinal Scottish legal treatises is perplexing. For example, no American judicial reference is found to the important, late seventeenth-century works of Sir George Mackenzie. ${ }^{56}$ Craig's Ius Feudale has been similarly ignored, although the fact that it was written in Latin may have had something to do with it. ${ }^{57}$ More unexpected is the American courts' omission of any reference to a number of the leading Scottish legal treatises of the eighteenth century, including those by Forbes ${ }^{58}$ Innes, ${ }^{59}$ and MacDouall (Lord Bankton). ${ }^{60}$ The leading works of nineteenth- and early twentiethcentury Scottish legal scholars have also suffered this fate. ${ }^{61}$

The paucity of American judicial references to Scottish legal scholars becomes more significant when compared to the widespread reference and reliance of American courts on the works of the leading English jurists such as Blackstone ${ }^{62}$ and Lord Coke. ${ }^{63}$ To date, almost 800 federal court opinions and over 1600 state court opinions contain citations to Blackstone: ${ }^{64}$ There were references to Blackstone in 82 pre-1900 U.S. Supreme Court cases alone. ${ }^{65}$ Similarly, there are at least 340 federal court cases with citations to Lord Coke, including well over 100 pre-1900 Supreme Court references. ${ }^{66}$

A look at the American judicial references to some of the leading 
non-Scottish civilian legal treatises is even more revealing of the insignificant impact Scots legal scholars had on the American judiciary. For example, at least 234 American federal court cases have cited or quoted from the works of Pothier, the famed French civilian scholar of the eighteenth century; ${ }^{67}$ similarly, there are 127 federal court references to Grotius, the Dutch jurist, including 70 pre-1900 Supreme Court citations. ${ }^{68}$

English translations and American editions provided American courts with a ready access to the works of Continental jurists. ${ }^{69}$ This factor does not explain the disparity between citations to Continental and Scottish jurists, it rather raises the question of why the Scots were not originally looked to more than their civilian brethren, given the lack of a language barrier, their significant representation in the American population, and their acknowledged dramatic influence in other areas of American development.

\section{Forum Non Conveniens}

The doctrine of forum non conveniens is one of the few areas in which some tangible evidence exists of Scots law influence upon American law. ${ }^{70}$ While the Latin designation of the term suggests a Continental origin, Scotland is the only civil law jurisdiction to which it has been traced. ${ }^{71}$ Indeed, the Supreme Court recently recognized Scotland as the doctrine's founding place. ${ }^{72}$

The request for dismissal in early Scottish cases was framed as "forum non competens," which suggested a plea questioning the court's capacity to deal with the issue before it. ${ }^{73}$ But as early as 1865 , it was recognized that the plea "usually does not mean that the forum is one in which it is wholly incompetent to deal with the question. The plea has received a wider significance, and it is frequently stated in reference to cases in which the court may consider it more proper for the ends of justice that the parties should seek their remedy in another forum." 74 As a result, the forum non conveniens term became accepted in Scotland in the late nineteenth century, ${ }^{75}$ although the concept was already firmly engrained in Scottish judicial philosophy.

The forum non conveniens term did not appear in American judicial opinions until $1917,{ }^{76}$ although state courts apparently exercised discretion to refuse to hear a case as to which they had jurisdiction as early as $1817,{ }^{77}$ and the practice was common in actions in admiralty. ${ }^{78}$ Blair's 1929 law review article, "The Doctrine of Forum Non Conveniens in Anglo-American Law," however, brought the term into common usage in the United States. ${ }^{79}$ Thereafter, the Supreme Court identified 
the doctrine by name in $1946,{ }^{80}$ although it had by the early 1930 s recognized the discretionary nature of a court's exercise of jurisdiction in "actions between nonresident foreigners for torts committed in a foreign country" 81 or "where for kindred reasons the litigation can more appropriately be conducted in a foreign tribunal." 82

A Scottish influence is apparent in these cases as well as in Blair's work. For example, in Williams v. Green Bay \& Western R. Co. ${ }^{83}$ the Supreme Court described and quoted from the leading Scottish case on forum non conveniens, Société du Gaz de Paris v. Armateurs français (as affirmed by the House of Lords) ${ }^{84}$ as well as a leading British treatise $^{85}$ to support the Court's general conclusion that the doctrine is one of fairness, intended to avoid undue hardship upon one of the parties who would otherwise be forced to litigate in an inappropriate forum. ${ }^{86}$ In both the seminal Gilbert decision ${ }^{87}$ and the earlier Canada Malting opinion, ${ }^{88}$ the Court referenced the Armateurs case, a leading English decision, and other sources as authority for the general right of courts to exercise discretion in declining jurisdiction. However, no such reference is contained in Koster v. Lumbermans Mutual Casualty Co. ${ }^{89}$ a companion case to Gilbert. Blair recognized the early development of forum non conveniens in Scotland, but stops short of stating that the doctrine originated there. ${ }^{90}$ Other commentators have recognized the early Scottish development of the doctrine and have acknowledged their inability to trace it back beyond Scotland..$^{91}$ However, their references to Scots law are for instructive and comparative purposes rather than to document a Scots heritage for the American forum non conveniens doctrine. ${ }^{92}$

The use of judicial discretion to decline to exercise jurisdiction in America extends back to the nineteenth century, long before the term forum non conveniens became frequently used..$^{93}$ These early decisions are devoid of any reference to Scottish authorities, ${ }^{94}$ leading to the conclusion that the doctrine developed in a somewhat parallel, but separate and independent, manner in the two countries. ${ }^{95}$

Nineteenth-century American admiralty courts also recognized their right to refuse jurisdiction in suits involving aliens. ${ }^{96}$ While the influence of English cases is apparent in these decisions, they contain no references to Scottish authorities.9"

Blair appears to have been the first to tie the state court and admiralty practice of sometimes refusing jurisdiction with the Scottish concept of forum non conveniens. From this we may infer that any Scots influence upon the American version of the doctrine has taken place in relatively recent times, rather than in the post-Revolutionary era or the nineteenth century. ${ }^{98}$ 
The evidence of contemporary influence is slight. It is important to note that with the exception of admiralty courts and the state courts in a few states like New York, forum non conveniens was slow to gain acceptance in the United States. ${ }^{99}$ The doctrine is well established now in most states and was codified in section 1404(a) of the 1948 Federal Judicial Code. ${ }^{100}$ However, modern decisions provide little evidence of Scottish influence. ${ }^{101}$

Thus, while American courts and commentators recognize Scotland as the origin of forum non conveniens, there is little evidence that the early Scots decisions had a significant influence in the development of the doctrine in the United States.

\section{Approbate and Reprobate}

Under Scots law, one may not accept a deed or legal instrument for one purpose and reject it for another. ${ }^{102}$ This Scottish concept, generally referred to as the doctrine of approbate and reprobate, is similar to the common law doctrine of election. ${ }^{103}$ While the doctrine of election was almost assuredly derived from the civil law, ${ }^{104}$ it is less certain that the English version came from the Scottish concept of approbate and reprobate. However, at least one English case strongly suggests this to be the case. ${ }^{105}$

The first reference in this country to a possible Scots law source for the American doctrine of election was probably the fourth edition of Bigelow's Law of Estoppel, which was published in $1886 .{ }^{106}$ In the fifth edition, published in 1890 , the relevant reference to Scots law was elevated from footnotes to the body of the text. ${ }^{107}$ The sixth edition, published in 1913, retained the Scots law reference and was thereafter the source for a significant number of American election cases acknowledging the possible Scots law origin of the doctrine. ${ }^{108}$ Bigelow's influence was most pronounced in Virginia, where at least seven cases cite his Scots law reference. ${ }^{109}$

Other early twentieth-century cases involving election refer to Scots law as authority for the doctrine without referring to Bigelow. ${ }^{10}$ Some opinions ${ }^{111}$ look to the House of Lords decision in Codrington $v$. Codrington, where Lord Cairns noted the similarity of Scots and English law. ${ }^{12}$ Still other cases apply the doctrine of approbate and reprobate without any reference to origin. ${ }^{113}$

Nonetheless, Bigelow's treatise and the significant number of election decisions quoting and citing it suggest that the Scots law of approbate and reprobate may have significantly influenced American law. A closer look, however, reveals that Bigelow cited English rather than Scots 
cases. ${ }^{114}$ Thus, the conduit for the American doctrine of election appears to be English law, which in turn derived the doctrine from civil law, although the House of Lords in the 1875 Codrington decision acknowledged its coexistence and similarity with the Scottish concept of approbate and reprobate. ${ }^{115}$ It may be that both the English and Scottish were independently influenced by Roman law, rather than the English borrowing from the Scottish. But from the American perspective, at least American courts were willing to borrow an equitable principle from what they believed were Scots law sources. However, there is little or no evidence that American jurists sought independent guidance from Scots sources; rather it appears that they were content with looking to English opinions such as Codrington or to Bigelow.

\section{Lord Campbell's Act}

Until the passage of Lord Campbell's Act in $1846,{ }^{116}$ the common law of England provided that no living person injured by the wrongful death of another could recover for that injury. The maxim that the cause of action died with the deceased was peculiarly English; ${ }^{117}$ Scots law had recognized wrongful death actions for relatives of the deceased since the eighteenth century. ${ }^{118}$

Lord Campbell was a Scot who attained distinction in England, serving variously as Chancellor of Ireland, Chief Justice on the Queen's Bench, and Lord Chancellor of Great Britain. ${ }^{119}$ The Act bearing his name has an obvious Scottish heritage since it limited actions to the loss of a wife, husband, parent or child by a wife, husband, parent, or child, just as did Scots law. ${ }^{120}$ In addition, the Act specifically excluded Scotland from its coverage, as Scots law already provided a suitable remedy for wrongful death. ${ }^{121}$

The subsequent passage of wrongful death statutes by American jurisdictions were heavily influenced by Lord Campbell's Act; some initial adoptions were almost verbatim. ${ }^{122}$ Thus, they necessarily incorporated Scots law, although again through an English conduit.

At least one American court looked directly to Scots law prior to legislative passage of Lord Campbell's Act. In Sullivan v. Union Pacific $R y .{ }^{123}$ the court specifically rejected the reasoning of Baker v. Bolton and relied on "the civil law, and the French and Scotch law" to provide for the recovery by a father for the wrongful death of his child. ${ }^{124}$

But the influence of Scots law on wrongful death actions pales when compared with that of English law. Prior to the various passages of Lord Campbell's Act in the United States, the United States Supreme Court and most other American courts, with few exceptions, relied 
exclusively on Baker v. Bolton to deny wrongful death actions to close relatives of the deceased. ${ }^{125}$ Lord Campbell's Act ultimately had a significant impact on American law, but it was an English statute and was viewed as such, probably with little American knowledge of its Scottish roots.

\section{Liability from the Game of Golf}

Not surprisingly, there is some evidence of Scots law influence on American law with regard to liability from golfing accidents. It is surprising, however, that the issue was apparently not considered, or at least reported, in Scotland until the 1905 Andrew v. Stevenson decision. ${ }^{126}$

In that case, the Sheriff's Court held a defendant not liable for personal injury resulting from a slice shot. The court ruled that a golfer would not be liable for a missed shot or even a failure to warn unless the plaintiff was in a position of foreseeable danger. Thus, in general, mere accidental shots were not sufficient to establish liability. ${ }^{127}$

Perhaps due to the paucity of any other authority, American courts have frequently looked to and followed the Andrew decision. ${ }^{28}$ However, other American decisions involving golfing accidents make no reference to Scots law. ${ }^{29}$

\section{Notice of the Defense of Alibi}

Traditionally, at common law all defenses except autrefois acquit, autrefois convict, and former pardon could be entered generally by an accused under a plea of not guilty. ${ }^{130}$ Given the lack of pretrial discovery in criminal cases, ${ }^{131}$ prosecutors found it difficult to prepare their cases because almost any defense could be asserted at trial without notice. In addition to the likelihood of surprise, the lack of notice was also thought to encourage the fabrication of alibis. ${ }^{132}$

Scotland had addressed this problem in 1887 by requiring criminal defendants to provide special notice of anticipated alibi defenses. ${ }^{133}$ In 1920 Professor Robert Millar urged, in a seminal article, that the Scottish practice of notice of alibi be adopted in the United States. ${ }^{134}$ It gradually gained acceptance here and by 1942 , fourteen states had adopted some form of the Scottish rule. ${ }^{135}$ In 1962, an alibi notice rule was recommended for inclusion into the Federal Rules of Criminal Procedure and was finally adopted in $1974 .{ }^{136}$

Today it is recognized that "American alibi-notice statutes trace their antecedents to a Scottish law enacted in 1887."137 While this is un- 
doubtedly correct, this legacy is principally the work of an American scholar who looked to Scotland and thus acted as a needed intermediary for American courts and legislatures.

\section{Worker's Compensation}

In the worker's compensation area there is some evidence, as in the golf cases, of American courts looking directly to Scottish decisions in the first decades of this century. In 1923, the Supreme Court looked to Scottish, American, and English precedents to support its finding of a causal relationship between employment and an employee's accident. ${ }^{138}$ In addition, some state courts also looked to Scottish authorities for guidance on the same issue, ${ }^{139}$ and a few more referred to Scots cases concerning the obligation of an injured employee to submit to appropriate medical care as a condition for compensation. ${ }^{140}$

Although one could make a case for a significant Scots law influence on American worker's compensation law, in reality the influence is slight. The cases citing Scottish authorities are relatively few and almost always look to English authority as well. More important, the bulk of Scottish cases were looked to for their interpretation of the Workman's Compensation Act of 1897. ${ }^{141}$ This act was a product of the British Parliament, and there is no evidence that it was peculiarly Scottish. ${ }^{142}$

\section{A Sketch of the Development of Scots Law}

Evidence of other Scots law influence on American law is sparse; ${ }^{143}$ it remains to explain the scant attention paid Scots law by early American lawmakers. A possible starting point is the strong Roman law influence on the development of Scots law, beginning with the medieval church and arguably continuing to the present. ${ }^{144}$ Scotland's long antagonism to England resulted in its strong resistance to English common law; Roman law, through the medium of canon law, had made significant inroads in Scotland by the time of its wars of independence in the late thirteenth and early fourteenth centuries and the break from England with the signing of the Treaty of Northampton in $1328 .{ }^{145}$

Thereafter through the early eighteenth century, it was commonplace for Scottish law students to be educated on the Continent, initially at Bologna in the north of Italy, and at Cologne and Louvain, then in France at Orleans and Avignon until the Reformation, and thereafter in Holland. ${ }^{146}$ Apparently the lack of Scottish universities (St. Andrews, 
the first, was founded in 1413) caused the initial exodus; even after their establishment, however, Scottish universities were slow to compete successfully with the legal instruction of the more famous Continental institutions. ${ }^{147} \mathrm{It}$ is noteworthy that by the early part of the seventeenth century, important Scottish legal scholars recognized that Roman law. was the principal source of Scots law. ${ }^{148}$

The publication of Stair's Institutions of the Law of Scotland in 1681 is the single most significant event in Scottish legal history. ${ }^{149}$ It largely succeeded in making "Scots law into a viable system and is properly regarded as the true foundation of modern Scots law." 150 Stair cited Roman sources frequently and was admittedly strongly influenced by it, though he stopped short of finding it binding in Scotland. ${ }^{151}$ Sir George MacKenzie, Stair's contemporary, whose own slighter institutional work dealt primarily with criminal law, also viewed Roman law as the principal source of Scots law. ${ }^{152}$ Subsequent institutional writers such as Forbes, Erskine, Bankton, and later Bell also paid homage to the role of Roman law, although Erskine in particular was disinclined to overstate its influence. ${ }^{153}$

The seventeenth and early eighteenth centuries brought the zenith of Roman law influence to Scotland, largely because of Stair's work and the established tradition whereby Scots lawyers were trained on the Continent. ${ }^{154}$ It is interesting that by the late eighteenth century, the influence of Scottish institutional works appears to have largely displaced that of Continental scholars, who were of course civilians as well. ${ }^{15 s}$

The late eighteenth century also saw a general decline in Roman influence on Scots law, at least with respect to new doctrine. The increased industrialization of society coupled with the marked development of English law often made resort to English law preferable to the more archaic Roman system, ${ }^{156}$ while the appellate jurisdiction of civil matters of the House of Lords undoubtedly resulted in an increased common law influence. ${ }^{157}$ Changes within Scotland apart from the Industrial Revolution also contributed to the decline in Roman law influence: The reorganization of the Court of Session (the supreme central court of Scotland, subject only to the House of Lords) and the regularization of publication of case reports led to greater reliance on case precedent and a decrease in the use of the Corpus Juris. ${ }^{158}$ Outside of Scotland, the Napoleonic Wars curtailed the study of Scots abroad. When continental countries subsequently began adopting civil codes, Scotland did not follow suit. Legal study in Europe thus became less attractive to Scots after the wars, which gradually reduced the influence of Continental legal systems in Scotland. 
Roman law remains one of the major historical sources of Scottish law, although its influence on new law in Scotland is negligible. ${ }^{159}$ It is still a significant part of the curriculum in Scottish law schools and much of Scots law, such as that on moveable property, delict (tort), and obligations, retains strong Roman characteristics. ${ }^{160}$

The early Scottish resistance to the English common law, while today diminished, has resulted in the continuation of a distinct Scottish legal system. ${ }^{161}$ This is in sharp contrast to what might have been: but for "non-legal historico-political factors," England, with "its power and proximity" and relatively developed legal system would have dominated the developing Scots law. ${ }^{162}$ Armed conflict between the two countries beginning in the late thirteenth century, coupled with ensuing antipathy and continuing hostilities, changed the probable course of history and led the Scots to look to the Continent and to Roman law for their legal heritage.

\section{Comparison with American Law Development}

While England did not enjoy the proximity to America that it did to Scotland, it certainly exercised considerable authority over its North American colony, so much so that the colonies eventually rebelled in open warfare and declared their independence. Unlike the Scots, however, the Americans failed to reject, at least for a meaningful time or with sufficient assurance, the English common law and failed to look to other legal systems for guidance with any real conviction.

Although Scotland and America both experienced strong anti-English feelings and both engaged in armed conflict with England, the parallel cannot be taken too far in comparing the two countries' receptivity to English law. England, after all, colonized America and successfully introduced the common law to the colonies at the earliest stages of the development of a legal system there. ${ }^{163}$ In contrast, Scotland's hostilities with England began at a time when it had an immature legal system, causing the Scots to look elsewhere for legal guidance as their society and thus their need for a system of laws advanced. ${ }^{164}$

Thus, although colonial America was a new country at the time of the American Revolution in 1776, it was a more modern society, and likely had a more evolved legal system than fourteenth-century Scotland did. Whereas displacement of a significant existing English law influence would have been necessary in post-Revolutionary America, there existed no English law influence in Scotland at the time Scottish-English hostilities began. 
The common law legacy in the United States is undoubtedly due in no small part to the common law foundation laid prior to the American Revolution. ${ }^{165}$ New or poorly developed legal systems borrow from others older and more mature. ${ }^{166}$ In colonial America, as with colonies throughout history, the colonizer's legal system was the initial, and thus most important, source for law.

\section{The Insignificance of Scots Law}

Nonetheless, immediate post-Revolutionary America faced a significant legal vacuum: Colonial law had produced no case reports or state precedents, American law treatises did not exist, and so few copies of English legal treatises were available that many courts had no access to them. ${ }^{167}$ There was also a desire to develop a responsive and "American" legal system during a time when antipathy toward England and its laws was intense. The opportunity was seemingly present for competing legal systems, in particular, one might think the Englishlanguage Scots civil law, to play a significant role in filling the void.

The resurgence of the legal profession and the common law in early nineteenth century America is well chronicled. ${ }^{168}$ Although post-Revolutionary Anglophobia was coupled with distrust of the concept of law generally, by 1820 both the legal profession and the common law were entrenched in American society. ${ }^{169}$ While civil law was not ignored, at least by those educated enough to refer to it, its role became more peripheral as the century wore on. The balance of the nineteenth century was largely left to the continued growth and refinement of the "American" common law.

It would appear that the window for significant "foreign" law ascendency was a thirty- to forty-year period following the Revolution. Although Kent and Story were well versed in Scots law and made ample references to the Scottish institutional writers in their own pathbreaking works, ${ }^{170}$ there is little other tangible evidence of Scots law influence during the post-Revolutionary period in America. Most of the American case citations to Scottish authorities occur in the latter half of the nineteenth century, when the courts were likely more influenced by Kent and Story than by Scottish sources. Kent and Story themselves, while certainly not strangers to the civil law, both embraced and promoted the common law as the way to a just society. ${ }^{171}$

Although the window for Scots law importation in the post-Revolutionary period was real, there appear a number of possible answers for the scant result. First, Scotland became a minority culture within 
the United Kingdom with the 1707 Union. Within Britain, it appears that post-Union, English law had a much greater impact on Scotland than the reverse, largely because of the unified Parliament dominated by the English. ${ }^{172}$ As a result, the exportation of English law as a part of British imperialism and colonization continued unabated. ${ }^{173}$

With respect to the American colonies, twelve of the original thirteen were founded before the Union and were therefore English colonies. That fact, coupled with the post-Union dominance of English law within Britain and Britain's legal imperialism policy with regard to its colonies, strongly suggests that Scots law had little chance to make a meaningful pre-Revolutionary impact in America. Furthermore, while a significant minority of Scots emigrated to the American colonies in the eighteenth century, ${ }^{174}$ including professionals (notably physicians), merchants, and landowners, its attraction for Scottish lawyers was apparently slight because of the perception that the English common law predominated and knowledge of Scots law was of no advantage. ${ }^{175}$

Of further importance were the Tory politics of many Scottish transplants during the American Revolution. While those of Scottish heritage were not Loyalist everywhere, they certainly were in some parts of the colonies, and the evidence suggests that the Scots were generally viewed as Tories. ${ }^{176}$ The outspoken opposition to colonial ambitions of a number of leading intellectuals in Scotland no doubt contributed to this popular perception. ${ }^{177}$

Thus, post-Revolutionary Anglophobia must have embraced, to some extent, Scotland. In addition, the paucity of Scottish emigrant lawyers suggests that American jurists may not have understood that Scots law was a civil law system, different and separate from English law. ${ }^{178}$ Although Story and Kent and certainly key figures such as Jefferson, Hamilton, and James Wilson were knowledgeable about and appreciated the Scots legal system, the relative inaccessibility of Scots law materials and the few Scots lawyers in America appear to have significantly impeded the post-Revolutionary acceptance of Scots law.

It may be imprudent to overestimate the legal void that occurred after the Revolution. Although colonial law varied greatly from colony to colony, the common law was its foundation and British statutes had full force and effect throughout. It is important to recall that the colonists' break with Great Britain was largely fueled by widespread hostility to British legislation and not by any particular aversion to the common law. ${ }^{179}$ The reaction against the common law occurred after the Revolution and was part of the general Anglophobia pervading the new country.

As jurists in America sought to create a distinct American juris- 
prudence, ${ }^{180}$ it is not surprising that increasing resort was had to the common law, if not substantively, then systemically. That is, even if some of the English common law principles were thought unjust or nontransferable, American jurists were ingrained and comfortable with the methodology of the common law. American lawyers at the time of Independence were unlikely to jettison the legal system that served as their livelihood. Furthermore, the necessity of having to rely heavily on a civil code or, as in the case of Scots law, the absence of judicial precedent and of a developing case law, hindered the acceptance of the civil law. As American cases were decided, were reported, and became precedent, the common law system was reaffirmed and meaningful resort to civil law systems was precluded. As a result, recourse to established common law principles became commonplace with civil law authority becoming secondary. Scots law appears to have been lost in the shuffle.

\section{NOTES}

The author would like to express appreciation to John Cairns and Alexander McCall-Smith for their warm support of this project. They along with Joseph McKnight, Werner Ebke, Beverly Carl, and Matthew Finkin gave helpful suggestions and provided insights which improved the final product. Errors are of course mine. Bruce Reemsnyder and Jim Rose, Jr., provided able research assistance. In addition, I owe special thanks to Lynn Talkington Rogers and Paul Talkington. I am also grateful to S.M.U. and to the Arthur and Linda Sarris Faculty Research Fund for providing generous research and travel support.

1. R. Pound, The Formative Era of American Law (1938). That period has also been called "the Golden Age of American Law," see THE GoLDEN AGE OF AMERICAN LAw (C. Haar ed. 1965) and "the Age of Discovery", see G. GiLmORE, THE Ages of American Law 19-40 (1977). See also D. Boorstin, The Americans: The NATIONAL EXPERIENCE 35 (1958) (nineteenth-century legal development in America one of the "creative outbursts of modern legal history").

2. See Hoeflich, Roman and Civil Law in American Legal Education and Research Prior to 1930: A Preliminary Survey, 1984 U. ILL. L. Rev. 719; Stein, The Attraction of the Civil Law in Post-Revolutionary America, 52 VA. L. REv. 403 (1966); Aumann, The Influence of English and Civil Law Principles Upon the American Legal System During the Critical Post-Revolutionary Period, 12 U. CIN. L. Rev. 289 (1938); Batiza, Sources of the Field Civil Code: The Civil Law Influences on a Common Law Code, 60 TULANE L. Rev. 799 (1986).

3. See, e.g., Turnbull, Scotland and America, 1730-1790, in A Hotbed of GenIus: The Scottish Enlightenment, 1730-1790 (D. Daiches, P. Jones \& J. Jones eds. 1986); A. Hook, SCotland and America: A Study of Cultural Relations 17501835 (1975); W. R. Brock, SCOtus Americanus: A SURVey of the Sources for 
Links between Scotland and America in the Eighteenth Century (1982); D. Sloan, The Scottish Enlightenment and the American College Ideal (1981); SCOTLAND, EUROPE AND THE AMERICAN ReVOlution (O. D. Edwards \& G. Shepperson eds. 1976); W. C. LehmanN, SCOTTISH AND SCOTCH-IRISH CONTRIBUtions to EARLY American Life and Culture (1978); and G. Wills, Explaining America: The FEDERALIST (1981). On the Scottish Enlightenment generally, see A HOTBED OF GENIUS, supra; B. LENMAN, INTEGRATION, ENLIGHTENMENT, AND INDUSTRIALIZATION: SCOTLAND 1746-1832 (1981); T. C. SMOUT, History OF THE SCOTTISH PeOPLe, 1560-1830 (1969); W. Ferguson, Scotland: 1689 to the Present (1968); N. T. Phillipson \& R. Mitchison, Scotland IN THe AGE of Improvement (1970); The ORIgins aNd Nature of the Scottish EnLightenment (R. H. Campbell \& A. Skinner eds. 1982).

4. G. Wills, INVENTING AMERICA: JeFFerson's DECLARATION OF INDEPENDENCE (1978). Wills argues that Jefferson was heavily influenced by eighteenth-century Scottish philosophy in drafting the Declaration of Independence. In a successor book, Wills argues that Madison and Hamilton were influenced by the Scottish Enlightenment, principally through Hume's political essays, in their work on the Constitution. G. Wilss, supra note 3. See also Walker, The Lawyers of the Scottish Enlightenment and their Influence on the American Constitution, 1988 JURIDICAL REv. 4.

5. They were John Witherspoon, the first president of Princeton University (then called the College of New Jersey) and James Wilson, later an associate justice of the Supreme Court. Benjamin Rush, an American physician trained at Edinburgh, was also a signatory. Witherspoon, along with other transplanted Scots such as William Small, Francis Alison, and William Smith, helped pattern American college curricula after those at Scottish universities and relied heavily upon the teachings of Scottish philosophers and other Scottish enlightenment figures to shape the content of the courses. See D. SlOAN, supra note 3; W. R. BROCK, supra note 3, at 92-93. Benjamin Rush was one of the founding members of the first medical school in America, in Philadelphia in the 1760s; Turnbull, supra note 3, at 141.

According to T. B. Smith, nine of the fifty-six signatories of the Declaration of Independence were Scots, as were twelve of the fifty-four delegates to the Constitutional Convention. T. B. Smith, British Justice: The SCottish CONTribution 45 (1961). Professor Smith also avowed that two of the original five Supreme Court Associate Justices, the second Chief Justice and two of Washington's original five member cabinet were of Scottish descent. Id. at 46. Of course, the Scottish descendency of some prominent statesmen does not necessarily suggest that their intellectual heritage was also Scottish.

6. See generally G. WILlS, supra note 3; Turnbull, supra note 3, at 149.

7. Madison was himself educated largely by Donald Robertson, a Scot who had trained at the universities of Aberdeen and Edinburgh. 1 I. BRANT, JAMES MADISON 60 (1941).

8. See G. SEeD, JAMES WILSON 37 (1978); Turnbull, supra note 3, at 149.

9. The lectures are contained in R. MCCLOSKEY, THE WORKS OF JAMES WILSON (1967). For biographic works see G. SEeD, supra note 8; C. P. SMITH, JAMES WILSON: FOUNDING FATHER, 1742-1798 (1956); Leavelle, James Wilson and the Relation of the Scottish Metaphysics to American Political Thought, 57 POL. SCI. Q. 394 (1942).

10. See Stein, supra note 2, at 407. See also G. GILMORE, supra note 1, at 19-26.

11. C. P. SMITH, supra note 9, at 312. As Professor Stein has pointed out, it was natural for Wilson, a Scot with no allegiance or even regard for English legal traditions, to urge an autonomous American legal system. Stein, supra note 2, at 407-8.

12. See L. Friedman, A History of American Law 97-98 (1973) citing E. G. 
Brown, British StatuTes in AmERICAN LAw 82, 132 (1964). Although the solutions differed, pre-Independence British statutes were typically ratified as part of the law of the state. L. FrIEDMAN, supra at 96-97.

13. See G. GILMORE, supra note 1, at 19-20.

14. See text accompanying notes 144-154, infra.

15. See, e.g., R. B. Sher, Church and Universities IN The Scottish ENLIGHTENMENT 274 (1985) quoting William Robertson, Principal of the University of Edinburgh (1762-93). See also Turnbull, supra note 3, at 145. There is some disagreement about Scottish public opinion of the American cause. Scottish disenchantment with the 1707 Union with England is argued to have been channeled into "the remarkably widespread sympathy" of the Scots for American independence. N. T. PHILliPson, Public Opinion and the Union, in SCOTLAND IN THE AGE OF IMPROVEMENT, supra note 3, at 126. Compare Swinfen, The American Revolution in the Scottish Press, in SCOTLAND, EuRope AND the AMERICAN Revolution, supra note 3, at 73 ("majority opinion opposed to American claims, and would have wished for outright victory . . .).

16. Turnbull, supra note 3 , at $145-46$.

17. See, e.g., Haws, The Scots in Colonial Virginia During the Revolutionary War, SCOTland, Europe AND THE AMERICAN Revolution, supra, note 3, at 99.

18. See text accompanying note 5, supra.

19. For example, Jefferson owned ten books of Kames as well as the works of nearly all of the authors of the Scottish Enlightenment. See G. WILLS, supra note 4, at 201; Walker, supra note 4, at 23. See also W. H. BRYSON, Census of LaW Books IN Colonial VIRGINIA (1978). (Bryson found three books of Kames and one "Laws of Scotland." Id. at 8, 26, and 59.)

20. W. R. BROCK, supra note 3, at 13-14.

21. Id. Germans apparently were more numerous overall, accounting for fully onethird of the population in Pennsylvania.

22. J. DALRYMPLE (Viscount Stair), InSTITUTIONS OF THE LAW OF SCOTLAND (1681) and G. MACKENZIE, THE INSTITUTIONS OF THE LAW OF SCOTLAND (1684). Stair's work was apparently substantially complete by 1664 although it was not published until 1681. See Hutton, Stair's Aim in Writing the Institutions in STAIR Tercentenary Studies 79 (Stair Society vol. 33, D. M. Walker ed. 1981).

23. See Cairns, Institutional Writings in Scotland Reconsidered in New PERSPECTIVES IN SCOTtISH Legal History 98 (A. Kiralfy \& H. L. MacQueen eds. 1984). See also D. M. Walker, The Scottish Jurists (1985); idem, Principles of Scottish Private LAW vol. 1, at 25 (3d ed. 1982); idem, The ScotTish Legal SySTEM 401-2 (5th ed. 1981); T. B. Smith, Scotland: The Development of its Laws and Constitution 32 (1962). Professors Walker and Smith consider institutional works to have the same authoritative value as the Inner House of the Court of Session (the appellate section of the court of general jurisdiction in Scotland). D. M. WALKER, THE SCOTTISH LEGaL SYSTEM, supra, at 402 and T. B. SMITH, supra, at 32. However, there is evidence that eighteenth-century Scots lawyers did not consider the institutional works to be as authoritative as have succeeding generations of the Scots bar. See Cairns, supra at 9899; Blackie, Stair's Later Reputation as a Jurist, in StaIR TERCENTENARY StUdies, supra note 22, at 207.

24. See Cairns, supra note 23, at 94. Bell's PRINCIPLES OF tHE LAw OF Scotland was published in 1829. His other institutional work was published in 1810 and was entitled COMmentaries ON THE LAW OF SCOTLAND AND ON THE PRINCIPLES OF MERCANTILE JURISPRUdENCE, CONSIDERED IN RELATION TO BANKRUPTCY; COMPOSI- 
TIONS OF CREDITORS; AND IMPRISONMENT FOR DEBT. This was actually the second edition of a two-volume work originally published in 1800-04 under the title, a TREatise on the Law of BanKRUPTCY IN SCOTLAND. Succeeding editions followed in $1816-19$ and 1821 .

25. See W. H. BRYSON, supra note 19.

26. According to David Walker, an edition of George Bell's INQUIRIES INTO THE Contract of Sale of Goods was published in Philadelphia. Professor Walker gives no date or authority for this assertion. D. M. WALKER, THE SCOTTISH JURISTS, supra note 23, at 350. See, e.g., Sir William Blackstone, Commentaries ON the Laws of England (G. Chase ed. 1922; G. Sharswood ed. 1859; T. Cooley ed. 1899); SIR EDWARD COKE, Institutes of THE LAWS of ENGLAND (T. Day ed. 1812; C. Butler ed. 1853).

27. See, e.g., 3 J. Kent, Commentaries on AMERICAN LAw 94, 116, 120, 124, 133 (1828). In the preface to his second (1832) edition, Kent remarks on the continuous improvements in each edition of Bell's works. $1 \mathrm{~J}$. KENT, supra at xi (2d ed. 1832). Kent also referred to J. Fergusson, Reports of Decisions by the CONSISTORIal COURT OF SCOTLAND IN ACTIONS OF DIVORCE, CONCLUDING FOR DISSOLUTION OF MARRIAGES CELEBRATED UNDER THE ENGLISH LAW. See, e.g., 2 J. KeNT, supra at 93 (1827). See generally Nadelmann, Joseph Story and George Joseph Bell, 1959 JURIDICAL REV. 31, 32.

28. See, e.g., J. Story, Commentaries on the Law of Bailments, sec. 2, n.2 (1832). For a thorough discussion of Story's knowledge of and use of civilian legal authorities see Hoeflich, John Austin and Joseph Story: Two Nineteenth-Century Perspectives on the Utility of the Civil Law for the Common Lawyer, 29 AM. J. LEGAL HIST. 36 (1985). See also Pound, The Place of Judge Story in the Making of American Law, 48 AM. L. REv. 676, 685 (1914).

29. See Nadelmann, supra note 27, at 36-39. Bell was visited in Edinburgh in August, 1838, by one of Story's favorite students, Charles Sumner. As a result of that visit, Bell wrote to Story and sent him copies of his PRINCIPLES OF THE LAW OF SCOTLAND and the three volumes, ILlustrations OF THE PRINCIPLES FROM ADJUDICATED CASES. Id. at 35-36. Bell's letter acknowledged the quality of Story's own work, stating that "it cannot fail to give us some little pain to see that you are, in great views and comprehensive learning, getting far before us." Bell then asserted that such erudition "will only exite us to that generous strife and emulation out of which may come universal improvement." Id. at 36.

30. Story's full sentence was as follows: "It was many years ago that my attention was first attracted to the highly cultivated state of jurisprudence in Scotland by the possession of a copy of Erskine's Institute, and the liberal use of your own excellent Commentaries on Commercial Law."

31. Id. at 38.

32. Story elaborated on this point as follows: "And I cannot but persuade myself, that in all cases of the conflict of laws they will find, as I have found, the most extensive information and accurate researches in the doctrines and decisions of your country." Id. at 39.

33. Strout v. Foster, 42 U.S. 89 (1843).

34. Benedict v. Schaettle, 12 Ohio St. 515 (1861); Palmer v. Dodge, 4 Ohio St. 21 (1854).

35. The Harrisburg, 119 U.S. 199, 202-03, 212 (1886) (two citations to Bell's Principles); The North Star, 106 U.S. 17, 20-21 (1882) (citation to Bell's Commentaries); 
Casey v. Cavaroc, 96 U.S. 467, 480-81 (1877) (citation to Bell's Commentaries); The Maggie Hammond, 76 U.S. 435, 452 (1969) (citation to Bell's Commentaries).

36. Keck v. United States, 172 U.S. 434, 461 (1899) (citation to Bell's Dictionary of Scottish Law and Lord Hume's Commentaries on the Laws of Scotland).

37. This occurs because of the early practice of reporting counsel's arguments and authorities relied upon before the Court. In all, ten citations to Bell in eight counsel arguments appear in the Supreme Court reporters. See The Max Morris, 137 U.S. 1, 5 (1890) (citation to the 5th edition of Bell's Commentaries); The Harrisburg, 119 U.S. 199, 202-03 (1886) (citation to Bell's Principles; referred to as Bell's "great work"); The Maggie Hammond, 76 U.S. 435, 441 (1869) (citation to Bell's Commentaries on Commercial Law, 1826 ed. and Erskine's Institutes); Harris v. Robinson, 45 U.S. 336, 341 (1846) (two citations to the 5th edition of Bell's Commentaries); Thomas Wilson and Co. v. Smith, 44 U.S. 763, 768 (1845); Rhett v. Poe, 43 U.S. 457, 477 (1844) (citation to Bell's Commentaries); Louisville, Cincinnati \& Charleston R.R. Co. v. Letson, 43 U.S. 497, 515, 520 (1844) (citation to Bell's Commentaries); Strout v. Foster, 42 U.S. 89, 94 (1843) (citation to Bell's Commentaries).

38. J. ERskine, The Principles of the Law of Scotland: In the ORder of Sir GEORGE MACKENZIE'S INSTITUTIONS OF THAT LAW, 2 vols. (1754). Twenty-one editions of the work were eventually published, with the last in 1911. D. M. WALKER, THE SCOTTISH JURISTS, supra note 23, at 208.

39. J. ERSKINE, AN INSTITUTE of the LAW OF SCOTLAND... IN THE ORdER of SiR George MacKenzie's Institutions of that LaW (1773). Seven more editions appeared, with the last in 1871. D. M. WALKER, THE SCOTTISH JURISTS, supra note 23, at 209.

40. See, e.g., J. Kent, Commentaries on American Law 50, 102, 106 (7th ed. 1851); J. Story, Commentaries on the Law of Parliament 29, 52, 269 (5th ed. 1851); J. STORY, EQUITY JURISPRUDENCE 228, 234 (12th ed. 1877); J. STORY, CONFLICT of LAwS 302, 401, 458 ( $2 \mathrm{~d}$ ed. 1846); J. STORY, COMMENTARIES ON THE LAW OF AGENCY 143, 620, 639 (3d ed. 1846); J. STORY, COMMENTARIES ON THE LAW OF PARTNERSHIP 17, 163, 403 ( $2 \mathrm{~d}$ ed. 1846). Story's letter to Bell suggests that he thought very highly of Erskine's Institutes. Nadelmann, supra note 27, at 38.

41. The Harrisburg, 119 U.S. 199, 212 (1886); Ennis v. Smith, 55 U.S. 400, 42425 (1852); Townsend v. Jemison, 50 U.S. 407, 417 (1850); Welzell v. Bussard, 24 U.S. 309, 318 (1826); Stevenson's Heirs v. Sullivant, 18 U.S. 207, 268-69 (1820); United States v. Smith, 18 U.S. 153, 180 (1820); Lanusse v. Barker, 16 U.S. 101, 158 (1818); Thompson v. Gray, 14 U.S. 75, 84-85 (1816); Wilder v. Inter-Island Steam Navigation Co., Ltd., 211 U.S. 239, 246 (1908). See also Chinn v. Ohio, 47 Ohio St. 575; 26 N.E. 986, 987 (1890). All citations are to Erskine's Institutes except that in Green v. Biddle, which is to Erskine's Principles.

42. Peabody v. United States, 231 U.S. 530, 533 (1913); Wilder v. Inter-Island Steam Navigation Co., 211 U.S. 239, 240 (1908); The Maggie Hammond, 76 U.S. 435, 441 (1869); Edmondston v. Drake and Mitchell, 30 U.S. 624, 629 (1831); United States v. Bevans, 16 U.S. 336, 361 (1818) (all citations to Erskine's Institutes).

43. Groves v. Slaughter, 40 U.S. 449, at xxiv of Appendix (1841) (two citations to Erskine and two to Kames; Erskine and Kames referred to as "those two great jurists"); Green v. Biddle, 21 U.S. 1, at 5 of Appendix (1823).

44. All four appeared in the actual judicial opinions of the cases reported. Ennis v. Smith, 55 U.S. 400, 424-25 (1852); Townsend v. Jemison 50 U.S. 407, 415 (1850); Green v. Biddle, 21 U.S. 1, at 5 of Appendix (1823); Clinton v. State, 33 Ohio St. 27, 32 (1877). 
45. D. Hume, Commentaries on the Law of Scotland, Respecting the DESCRIPTION AND PUNISHMENT OF CRIMES, 2 vols. (1797). Successive editions were published in 1819,1829 , and 1844. D. M. WALKER, THE SCOTTISH JURISTS, supra note 23, at 330. Hume served as professor of Scots Law at the University of Edinburgh from 1786 until 1822, where he preceded George Bell. Id. at 317-19.

The three cases citing Hume include, surprisingly, a 1974 Supreme Court decision, Keck v. U.S., 419 U.S. 256, 261 n.3 (1974). See also Schick v. Reed, 172 U.S. 434, 461 (1899) (dissenting opinion); People of New York v. Wilson, 141 N.Y. 185, 36 N.E. 230 (1894) (counsel).

46. A. Alison, Principles of the Criminal Law of Scotland (1832). See also idem, Practice of the Criminal Law of Scotland (1833).

47. People of New York v. Wilson, 141 N.Y. 185, 36 N.E. 230, (1894) (counsel).

48. H. Home (Lord Kames), Principles OF EQUITY (1760). Five editions of the work eventually appeared, with the last in 1825 . D. M. WALKER, THE SCOTTISH JURISTS, supra note 23 , at 232.

49. Story believed that such an approach would lead to unbridled jurisdiction and judicial activism. In contrast, Benjamin Franklin, who became a close friend of Kames during a trip to Edinburgh in 1759, wrote Kames (in May, 1760) that his Equity "will be of the greatest Advantage to the Judges in our colonies" and advised that he had sent a copy to a judge on the Supreme Court of Pennsylvania. I. S. Ross, LORD KAMES AND THE SCOTLAND OF HIS DAY 245 (1972).

Lord Kames was one of the leading figures of the eighteenth-century Scottish Enlightenment and wrote, in addition to six books on the law, on a broad range of topics, including morality, natural religion, literary criticism, history, education, culture, and agricultural improvement. Kames is acknowledged to have had a major impact on the thinking of Thomas Jefferson and John Adams. On Kames, in addition to Ross, supra, see W. C. Lehmann, Henry Home, Lord Kames, and the Scottish ENLIGHTENMENT (1971).

50. See A. E. Anton, Private International Law 11-12 (1967). See also Johnston, The Scottish Tradition in International Law, 16 CAN. YEARBOOK ON INT'L L.3 (1978).

51. See note 32, supra. Story frequently cited Kames's PRINCIPLES OF EQUITY in his own writings. See, e.g., J. StORY, COMMENTARIES ON THE CONFlict OF LAws, supra note 40 , at $420,421,502,503$; J. STORY, EQUITY JURISPRUDENCE, supra note 40, at 9, 13, 618-19; J. STORY, COMMENTARIES ON THE LAW OF PROMISSORY NOTES 186, 195 (1845).

52. Wisconsin v. Pelican Insurance Co., 127 U.S. 265, 291 (1888). (Equity passage quoted in opinion and referred to as having been "cited and approved by Mr. Justice Story in his Commentaries on the Conflict of Laws"); Aspden v. Nixon, 45 U.S. 467, 470, 487, 492 (1846) (counsel); Groves v. Slaughter, 40 U.S. 449, at xxiv of Appendix (1841); Barker v. State, 62 Ohio St. 2d 35, 39, 402 N.E. 2d 550, 553 (1980) (opinion quoting Kames and citing Story's Commentaries on the Conflict of Laws).

53. H. Home (Lord Kames), Historical Law Tracts (1759). Four more editions of work appeared in 1761, 1776, 1792 and 1817, respectively. A French translation was published in 1766 . W. C. LEHMANN, supra note 49 , at 341 .

54. See I. S. Ross, supra note 49 , at 202-21.

55. Id. at 218-19; W. C. LeHMANN, supra note 49, at 217-18. See also idem, supra note 3 , at 159-60, 163, 165-66.

56. G. Mackenzie, The Laws and Customs of Scotland in Matters Criminal (1678); idem, THE InSTITUTIONS OF THE LAW OF SCOTLAND (1684). A second edition of Mackenzie's Customs appeared in 1699 while eight editions of his Institutes were 
published through 1758 , with an additional London edition appearing in 1694. See Cairns, supra note 23, at 91, 99, 101; D. M. WALKER, ThE SCOTTISH JURISTS, supra note 23, at 162, 166. For a further example of Mackenzie's work see G. MACKENZIE, Observations upon the Laws and Customs of Nations as to Precedency: With the Science of Heraldry, treated as a PaRT of the Civil Law and the Law of NATIONS (1680).

57. T. Craig, Ius Feudale (1655). The limited subject matter of the work also undoubtedly was a factor.

58. W. Forbes, The Institutes of The Law of Scotland, Volume First Comprehending the Private LaW (1722); idem, The InSTITUTES of the LaW of SCotland, Volume Second, Comprehending the Criminal law (1730).

59. J. INNES, IDEA JURIS SCOTICI; OR, A SUMMARY VIEW OF THE LAWS OF SCOTLAND (1733).

60. A. MacDouall (Lord Bankton), AN Institute of the Laws of Scotland IN Civil Rights: With OBSERVATIONS UPON THE AGREEMENT OR DiVERSITY BETWEEN them and the LaWs of England. In Four BoOKS, after the General Method OF THE VISCOUNT OF STAIR's INSTITUTIONS 3 vols. (1751-53).

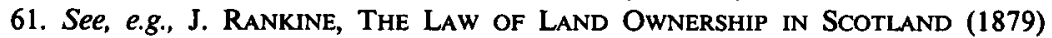
(four editions through 1909); W. Gloag, The LaW of Contract: A Treatise on the Principles of Contract in the Law of Scotland (1913) (2d ed. 1929); W. Gloag \& R. HENDERSON, INTROduction to THE LAW OF SCOTLAND (1927) (currently in the ninth edition).

62. W. Blackstone, Commentaries on the Laws of England 4 vols. (176569). Among the extensive literature on Blackstone see especially Cairns, Blackstone, an English Institutist: Legal Literature and the Rise of the Nation State, 4 OXFORD J. LeGal STUD. 318 (1984); Doolittle, Sir William Blackstone and his Commentaries on the Laws of England (1765-69): A Biographical Approach, 3 OXFORD J. LEGAL STUD. 99 (1983); Hanbury, Blackstone in Retrospect, 66 LAW Q. REv. 318 (1950); Kennedy, The Structure of Blackstone's Commentaries, 28 Buffalo L. Rev. 205 (1979); Milsom, The Nature of Blackstone's Achievement, 1 OXFORD J. LEGAL STUD. 1 (1981); and McKnight, Blackstone, Quasi-Jurisprudent, 13 Sw. L. J. 399 (1959). On Blackstone's influence on American Law, see Nolan, Sir William Blackstone and the New Republic: A Study of Intellectual Impact, 51 N.Y.U. L. Rev. 731 (1976) and A. WATSON, LEGAL TransPlants: AN APPROACH TO COMPARATIVE LAW 93-94 (1974).

63. See, e.g., E. Coke, The First Part of the Institutes of the Laws of ENGLAND; OR, A COMMENTARY ON LITTLETON: NOT THE NAME OF THE AUTHOR ONLY, BUT OF THE LAW ITSELF (1628). The second, third, and fourth Institutes were published in 1642-44 after Lord Coke's death in 1628.

64. The opinions range from the recent to the early. See, e.g., Ford v. Wainright, 477 U.S. 399, 406-08 (1986); G. M. Mosley Contractors v. Phillips, 487 So. 2d 876, 878 (Ala. 1986) and Chisholm v. Georgia, 2 U.S. 419, 437 (1793); Calder v. Bull, 3 U.S. 386, 391 (1798).

65. See, e.g., U.S. v. Wong Kim Ark, 169 U.S. 649, 659 (1898); Hurtado v. California, 110 U.S. 516, 538 (1884); Davis v. Gray, 83 U.S. 203, 230 (1872); Croxall v. Shererd, 72 U.S. 268, 285 (1866); U.S. v. Wood, 39 U.S. 430, 437 (1840); Smith v. Bell, 31 U.S. 68, 75 (1832); U.S. v. Smith, 18 U.S. 153, 162 (1820); Marbury v. Madison, 5 U.S. 137, 168 (1803); Chisholm, Ex'r. v. Georgia, 2 U.S. 419, 437 (1793).

66. See, e.g., Fink v. O'Neil, 106 U.S. 272, 285 (1882); McVeigh v. United States, 78 U.S. 259, 265 (1870); Sheets v. Selden's Lessee, 69 U.S. 177, 182 (1864); Roberts v. Cooper, 61 U.S. 467, 471 (1857); Mitchell v. Harmony, 54 U.S. 115, 143-44 (1851). 
67. See, e.g., United States v. Wong Kim Ark, 169 U.S. 649, 666 (1898); Meyer v. Richards, 163 U.S. 385, 401 (1896): Geer v. Connecticut, 161 U.S. 519, 524 (1896); Meechan v. Valentine, 145 U.S. 611,620 (1892); New Orleans v. Gaines's Administrator, 138 U.S. 595, 608 (1891); Illinois Central R.R. Co. v. Bosworth, 133 U.S. 92, 101 (1890); Henderson v. Wadsworth, 115 U.S. 264, 280 (1885); Jackson v. Ludeling, 99 U.S. 513, 529 (1878); Burbank v. Conrad, 96 U.S. 291, 308 (1877) (dissent).

The number of references to Pothier is somewhat misleading due to a number of Fifth Circuit diversity cases applying Louisiana law and thus referring liberally to civilian authorities. See, e.g., Perkins v. F.I.E. Corp., 762 F.2d 1250, 1261 n.34 (5th Cir. 1985); Celestin v. Employers Mutual Liability Insurance Co. of Wisconsin, 387 F.2d 539, 541 (5th Cir. 1968); Williams v. Employers Liability Assurance Corp., 296 F.2d 569, 571 n.4 (5th Cir. 1961).

68. See, e.g., Keith v. Clark, 97 U.S. 454, 463 (1878); Hanger v. Abbott, 73 U.S. 532, 540 (187); Scott v. Sandford, 60 U.S. 393, 484 (1856); The New Jersey Steam Navigation Co. v. Merchants Bank of Boston, 47 U.S. 344, 415 (1848); United States v. Percheman, 32 U.S. 51, 68 (1833); Ogden v. Sanders, 25 U.S. 213, 222 (1827); The Schooner Exchange v. M'Faddon, 11 U.S. 116, 133 (1812); Emory v. Grenough, 3 U.S. 369, 371 (1797); Hoare v. Allen, 2 U.S. 102, 109 (1789).

69. See, e.g., R. J. Pothier, A Treatise on Maritime Contracts of Letting to Hire (C. Cushing trans. 1821); idem, A Treatise on the Law of Obligations (W. Evans trans., 3d Amer: ed. 1853). See also Aumann, supra note 2, at 310-11.

70. Forum non conveniens concerns the discretionary power of a court to decline to exercise jurisdiction that it rightfully has "whenever it appears that the cause before it may be more appropriately tried elsewhere." Blair, The Doctrine of Forum Non Conveniens in Anglo-American Law, 29 ColuM. L. Rev. 1 (1929). See also Gulf Oil Corp. v. Gilbert, 330 U.S. 501, 507 (1947) ("The principle ... is simply that a court may resist imposition upon its jurisdiction even when jurisdiction is authorized by the letter of a general venue statute.").

71. See Braucher, The Inconvenient Federal Forum, 60 HARV. L. REv. 908, 909-11 (1947). One commentator acknowledged that the doctrine was long established in Scotland and England, but opined that its use was probably borrowed from some continental legal system. He could point to no evidence, however, that demonstrated another origin. Dainow, The Inappropriate Forum, 29 ILL. L. REv. 867, 881 \& n.58 (1935).

72. Piper Aircraft Co. v. Reyno, 454 U.S. 235, 248 n.13 (1981). See also Baltimore \& Ohio R. v. Kepner, 314 U.S. 44, 55-56 (1941) (Frankfurter J., dissenting) (forum non conveniens a "manifestation of a civilized judicial system ... firmly imbedded in our law").

73. See Longworth v. Hope, 3 Macph. 1049, 1053 (1865). See also Braucher, supra note 71, at 909, citing Brown's Trustee v. Palmer, 9 Sess. Cas. 224 (1830); MacMaster v. MacMaster, 11 Sess. Cas. 685 (1833).

74. Longworth v. Hope, 3 Macph. 1049, 1053 (1865).

75. See, e.g., Lynch v. Stewart, 9 Macph. 860, 862 (1871); Macadam v. Macadam, 11 Macph. 860, 861 (1873); Prescott v. Graham, 20 Scot. L. Rep. 573, 574 (1883); Sim v. Robinow, 19 Sess. Cas. (4th ser.) 665, 666 (1892). See also A. ANTon, supra note 50 , at $148-50$.

76. Bagdon v. Phila. \& R. C. \& I. Co., 178 App. Div. 662, 165 N.Y. Supp. 910 (2d dept. 1917). See Blair, supra note 70 , at 2 n.4.

77. Gardner v. Thomas, 14 Johns. 134 (N.Y. 1817). See Braucher, supra note 71, at 914 and Blair, supra note 70 . 
78. See Bickel, The Doctrine of Forum Non Conveniens as Applied in the Federal Courts in Matters of Admiralty, 35 CORNELL L.Q. 12 (1949); Coffey, Jurisdiction over Foreigners in Admiralty Courts, 13 CALIF. L. REv. 93 (1925).

79. 29 Colum. L. Rev. 1 (1929). See Barrett, The Doctrine of Forum Non Conveniens, 35 Calif. L. Rev. 380, 388 (1947).

80. Williams v. Green Bay \& W.R. Co., 326 U.S. 549, 551, 553, 554 (1946). See also Gulf Oil Corp. v. Gilbert, 330 U.S. 501 (1947) and Koster v. Lumberman's Mutual Co., 330 U.S. 518 (1947).

81. Langnes v. Green, 282 U.S. 531, 544 (1931).

82. Canada Malting Co. v. Paterson Steamships, Ltd., 285 U.S. 413, 423 (1932).

83. 326 U.S. 549,555 n. 4 (1946).

84. Société du Gaz de Paris v. Armateurs français, [1926] Sess. Cas. 13 (H.L.).

85. A. GibB, INTERNATIONAL LAW OF JURISDICTION 212-13 (1926).

86. While recognizing the general validity of the doctrine, the Williams Court held that the district court had applied it improperly on the facts before it. 326 U.S. at 55960.

87. Gulf Oil Corp. v. Gilbert, 330 U.S. 501, 507 n.6 (1947).

88. Canada Malting Co., v. Paterson Steamships, Ltd., 285 U.S. 413, 423 n.6 (1932).

89. 330 U.S. 518 (1947).

90. Blair, supra note 70 , at 2 .

91. Braucher, supra note 71, at 909; Dainow, supra note 71, at 881; Barrett, supra note 79 , at $386-87$.

92. See Blair, supra note 70 , at 29,33 . Blair seemingly apologizes for his look at Scottish law, stating "While an examination of Scotch decisions may seem irrelevant in an article dealing with Anglo-American law, yet the greater vogue of the plea of forum non conveniens in Scotland than in England ... coupled with the natural facility of Scotch judges for terse generalizations, will, we trust, be accepted as justifications for the irrelevance." Id. at $20 \mathrm{n} .91$. This suggests that he saw no real Scots law influence in American law as then developed. See also Braucher, supra note 71, at 932; Dainow, supra note 71 , at $881-86$.

93. See Blair, supra note 70, at 21-29; Braucher, supra note 71, at 914; Barrett, supra note 79 , at 387.

94. The earliest American cases involved suits between aliens on disputes which arose abroad, see, e.g., Gardner v. Thomas, 14 Johns. 134, 7 Am. Dec. 445.(N.Y. 1817); Great Western Ry. v. Miller, 19 Mich. 305 (1869); Johnson v. Dalton, 1 Cow. 543, 13 Am. Dec. 564 (N.Y. 1823). A few nineteenth-century decisions recognized discretion to refuse jurisdiction where the plaintiff was resident of another state of the United States, see, e.g., Pierce v. Equitable Life Assurance Society, 145 Mass. 56, 12 N.E. 858 (1887); Molony v. Dows, 8 Abb. Pr. 316 (1859); Ferguson v. Neilson, 11 N.Y. Supp. 524 (1890); Morris v. Missouri Pacific Ry., 78 Tex. 17, 14 S.W. 228 (1890).

95. See Barrett, supra note 79, at 387. In Piper Aircraft Co. v. Reyno, 454 U.S. 246, 248 n.13 (1981) the Supreme Court stated that the doctrine of forum non conveniens "originated in Scotland ... and became part of the common law of many states." The statement appears to be inaccurate to the extent that it suggests Scots law was responsible for or influenced the state common law development.

96. See Coffey, supra note 78; Bickel, supra note 78; Comment, Admiralty Suits Involving Foreigners, 31 TEXAS L. REv. 889 (1953).

97. See, e.g., The Belgenland, 114 U.S. 355 (188); Panama R.R. v. Napier Shipping Co., 166 U.S. 280 (1897); One Hundred \& Ninety-four Shawls, Fed. Cas. No. 10,521 
(S.D.N.Y. 1848). See Bickel, supra note 78, at 19 (admiralty courts borrowed forum non conveniens concept from English cases); Coffey, supra note 78, at 94-95.

98. See notes 75-81, supra.

99. One commentator, writing in 1947 , stated that only half a dozen states had then accepted the doctrine while fourteen states had rejected it. The remaining bulk of state jurisdictions had yet to consider its applicability. Barrett, supra note 79 , at 388-89 \& n. 40-41.

100. 28 U.S.C. Sec. 1404(a) (1976). The statute does not replace the doctrine of forum non conveniens but rather ameliorates its harshness by providing for a change of venue rather than dismissal of the cause of action where the preferred forum is another federal court. See Norwood v. Kirkpatrick, 349 U.S. 29 (1955). Dismissal of a cause of action by a federal court under the traditional doctrine is thus appropriate only when the preferred forum is a court in a foreign country or a state court. See Gross v. Owen, 221 F.2d 94, 96 (D.C. Cir. 1955) (no other federal court available) and Simon v. Silfen, 247 F. Supp. 762, 763 (S.D.N.Y. 1965) (parallel state action pending). See generally J. Friedenthal, M. Kane \& A. Miller, Civil Procedure 90-93 (1985); Kitch, Section 1404(a) of the Judicial Code: In the Interest of Justice or Injustice? 40 IND. L.J. 99 (1965); Note, Forum Non Conveniens and American Plaintiffs in the Federal Courts, 47 U. CHI. L. REv. 373, 377 (1980).

101. See, e.g., Silver v. Great American Ins. Co., 29 N.Y.2d 356, 328 N.Y.S.2d 398, 278 N.E.2d 619 (1972); Thomson v. Continental Ins. Co., 66 Cal. 2d 738, 59 Cal. Rptr. 101, 427 P.2d 765 (1967); Lonergan v. Crucible Steel Co. of America, 37 Ill. 2d 599, 229 N.E.2d 536 (1967). Compare Zurick v. Inman, 221 Tenn. 393, 426 S.W.2d 767 (1968) ("The origin of the doctrine is somewhat obscure and from our research it appears to have originated in Scotland. ..."). See also Note, Developments in the LawState-Court Jurisdiction, 73 HARV. L. REv. 909, 1009 n.648 (1960) (recognizing Scottish origins of doctrine).

102. 1 Bell's COMMENTARIES ON THE LAWS OF SCOTLAND 64 sec. 32 (6th ed. 1858).

103. In Codrington v. Codrington, L.R. 7 H.L. 854, 861-62 (1875) Lord Cairns specifically recognized this commonality when he observed: "By the well-settled doctrine which is termed in the Scotch law the doctrine of 'approbate' and 'reprobate,' and in our Courts more commonly the doctrine of 'election', where a deed or will professes to make a general disposition of property for the benefit of a person named in it, such person cannot accept a benefit under the instrument without at the same time conforming to all its provisions, and renouncing every right inconsistent with them."

104. "The doctrine of election, like many other doctrines of equity jurisprudence, appears to have been derived from the civil law." J. STORY, supra note 40, at sec. 1078.

105. Justice Chitty, writing in In Re Chesham, 31 Ch.D. 466, 473 (1886), observed that "[t]he principle on which the doctrine of election is based is that a man shall not be allowed to approbate and reprobate; that if he approbates he shall do all in his power to confirm the instrument which he approbates. The consequences of such a principle cannot be legitimately caried beyond the principle itself; if a man approbates, his obligation is confined to his adopting the instrument as a whole and abandoning every right inconsistent with it."

106. M. Bigelow, A Treatise on the LaW of Estoppel and Its Application IN PRACTICE ch. 19 (4th ed. 1886). Story recognized the civil law origins of election but did not specifically identify Scotland as a source. See note 104, supra.

107. M. Bigelow, supra note 106, at 673 (5th ed. 1890).

108. The most commonly quoted language was: "A party cannot either in the course of litigation or in dealings in pais, occupy inconsistent positions. Upon that 
rule election is founded: 'a man shall not be allowed', in the language of the Scotch law, 'to approbate and reprobate.' And where a man has an election between several inconsistent courses of action, he will be confined to that which he first adopts; the election, if made with knowledge of the facts, is in itself binding. . .." M. BIGELOw, supra note 106, at 733 (6th ed. 1913).

Cases citing the "Scotch law" reference in Bigelow's sixth edition include: Brooks \& Co. v. North Carolina Pub. Serv., 37 F.2d 220, 224 (4th Cir. 1930); Stroh Brewery Co. v. Grand Trunk W. R.R., 513 F. Supp. 827, 834 (E.D. Mich. 1981); Metcalfe Bros. v. American Mut. Liab. Ins., 484 F. Supp. 826, 831 (W.D. Va. 1980); Griley v. Griley, 43 So. 2d 350, 352 (Fla. 1949); Jones v. Neibergall, 42 So. 2d 443, 444 (Fla. 1949); Arwood v. Hill's Adm'r, 117 S.E. 603, 606 (Ga. Ct. App. 1923); Riley v. Cumberland \& Manchester R. Co., 29 S.W.2d 3, 4 (Ky. 1930); Jones v. Southern Natural Gas, 213 La. 1051, 36 So. 2d 34, 40 (1948); Petillo v. Stein, 42 A.2d 675, 678 (Md. 1945); Herring v. Citizens Bank \& Trust, 21 Md. App. 517, 321 A.2d 182, 196 (1974); Mertz v. Mertz, 311 Mich. 46, 18 N.W.2d 271 (1945); Castle v. Tracy, 463 S.W.2d 777, 780 (Mo. 1971); State Ex. Rel. Hilleary \& Partners v. Kelly, 448 S.W.2d 926, 931 (Mo. Ct. App. 1969); United States Nat'l. Bank of Red Lodge v. Chappell, 230 P. 1084, 1088 (Mont. 1924); Tremarco v. Tremarco 174 A. 898, 899 (N.J. 1934); Tate v. Estate of Dickens, 276 App. Div. 94, 93 N.Y.S. 504, 507 (1949); Pulaski Nat'l. Bank v. Harrell, 203 Va. 227, 123 S.E.2d 382, 387 (1962); Rohana v. Vazzana, 196 Va. 549, 84 S.E.2d 440, 442 (1954); Burch v. Grace St. Bldg. Corp., 191 S.E. 672, 677 (Va. 1937); Dickenson v. Boyd, 187 S.E. 479, 480 (Va. 1936); Hurley v. Bennett, 176 S.E. 171, 175 (Va. 1934); Nagle v. Syer, 143 S.E. 690,692 (Va. 1928); Title Guarantee Trust \& Savings Bank v. Clifton Forge Nat'l. Bank, 140 S.E. 272, 274 (Va. 1927).

109. Pulaski Nat'l Bank, 123 S.E.2d at 387; Rohanna, 84 S.E.2d at 442; Burch, 191 S.E.2d at 677; Dickenson, 187 S.E.2d at 480; Hurley, 176 S.E.2d at 175; Nagle, 143 S.E.2d at 692; Title Guarantee Trust \& Savings Bank, 140 S.E.2d at 274.

110. See, e.g., United States National Bank of Red Lodge, 230 P. 1084, 1088 (Mont. 1924). "Now the plaintiff must either ratitfy this transaction in whole or reject it in whole. It must take the bad with the good; it will not be permitted to blow both hot and cold. As under the Scots law, [he] will not be permitted to approbate and reprobate."

111. Noyes v. Noyes, 233 Mass. 55, 123 N.E. 395, 396 (1919); Jones v. Neibergall, 42 So. 2d 443 (1949).

112. Codrington v. Codrington, L.R. 7 H.L. 854 (1875). See note 103, supra.

113. Brooks \& Co. v. North Carolina Public Service Co. 37 F.2d 220, 224 (1930); Stroh Brewery v. Grand Trunk Western R.R., 513 F. Supp. 827, 834 (1981); Riley v. Cumberland \& Manchester R.R., 29 S.W.2d 3, 4 (1930).

114. M. Bigelow, supra note 108 , at $732 \mathrm{n} .3$, citing In re Chesham, $31 \mathrm{Ch}$. D. 466, 473, Chitty, J; Steward v. Muirhead, 29 N.B. 273, Carter, J.

115. See note 103, supra and accompanying text.

116. The Fatal Accidents Act, 9 \& 10 Vict. ch. 93 (1846) (more commonly known as Lord Campbell's Act).

117. See Malone, The Genesis of Wrongful Death, 17 Stan L. REv. 1043, 1044 (1965).

118. See Clarke v. Carfin Coal Co., (1891) A.C. 412, 418 (Scot) where Lord Watson noted that "[a]s a matter of fact, it cannot be disputed that ... for a century past, actions for solatium and damages have been sustained at the instance of husband, wife, or legitimate child, in respect of the death of a spouse, a child, or a parent ... in the law of Scotland."

119. See L. Denning, Borrowing from Scotland 27 (1963). 
120. A young Lord Campbell, sitting as a law reporter, was forced to report the controversial Baker v. Bolton decision [(1808) 1 Camp. 493], which ruled that the death of a human being could not be complained of as an injury and was, thus, not compensable. According to Lord Denning, Campbell thought the case wrongly decided and determined to change English law to conform to the Scottish as soon as the opportunity arose. L. DenNing, supra note 119, at 28-29.

Baker v. Bolton has been roundly criticized by scholars since, among other things, it makes it more advantageous, from a tort perspective, for a defendant to kill rather than injure a person. According to Prosser, "Lord Ellenborough [the decision's author], whose forte was never common sense, held without citing any authority that a husband had no action for loss of his wife's services through her death. ..." W. ProsSER, TORTS 901 (4th ed. 1971). See also SPEISER, ReCOVERY FOR WrONGFUl DEATH 7 (1966) ("it is clear that the rule in Baker v. Bolton was not based on precedent or logic").

121. See Morange v. State Marine Lines, 398 U.S. 375, n.13 [quoting in part from Admiralty Commissioners v. S.S. Amerika, (1917) A.C. 38, 52]. According to Justice Harlan, "[t]he decisional law of Scotland had long recognized [the] right to recover for wrongful death; thus, the mischief at which the statute [was] aimed could be cured without disturbing Scottish law. The Act 'excluded Scotland from its operation because a sufficient remedy existed there when in England none [had] existed at all."

The Scottish position is succinctly stated in Eisten v. North British Ry., 8 Macph. 980, 984, 42 Scot. Jur. 575 (1870) ("It is true that, in the law of Scotland, differing in that respect from some other systems of jurisprudence, a claim of this kind is sustained at the instance of a wife for the death of a husband, a husband for the death of his wife, a parent for the death of his child, and a child for the death of his parent, where the death has been caused by delict or culpa.").

122. See, e.g., the discussion of the North Carolina "Lord Campbell's Act" in Hume v. Long, 377 S.E.2d 99, 101 (S.C. Ct. App. 1988). See also Morange v. States Marine Lines, 398 U.S. 375, 390 (1969); Cant v. Bartlett, 440 A.2d 388, 393 (Md. 1982); Goheen v. General Motors Corp., 502 P.2d 223, 227 (Ore. 1972); In re Meng, 96 Misc. 126, 159 N.Y.S. 535, 538 (1916).

123. 23 Fed. Cas. 368 (D. Neb. 1874).

124. Id. at 369. Judge Dillon specifically rejected Baker v. Bolton: "Considering that it is not reasoned and cites no authorities, and the time it was made, and that the rule it declares is without any reason to support it, my opinion is that it ought not to be followed in a state where the subject is entirely open for settlement." Id. at 371 .

125. Professor Malone has noted that Baker v. Bolton "was consistently ignored in America until $1848 \ldots$ and during this forty-year interval there was no instance of a denial of a civil action for wrongful death." However, beginning with Carey v. Berkshire R.R., 55 Mass. (1 Cush.) 475, 48 Am. Dec. 616 (1848), the trend reversed and Baker v. Bolton was used to deny actions for wrongful death. Malone, supra note 117 , at 1067.

In The Harrisburg v. Rickards, 119 U.S. 199, 205 (1886), the Supreme Court held that "by common law, no civil action lies for an injury which results in death.... The only American cases in the common law courts against this rule, to which our attention has been called, are, Cross v. Guthery, 2 Root 90, 1 Am. Dec. 61 (1794); Ford v. Monroe, 20 Wend. 210 (1833); James v. Christy, 18 Mo. 162 (1853); Sullivan v. Union Pacific Ry., 3 Dillon 334 (1874)." The Court then noted that each of these decisions had been overturned. The Court appears to have missed some earlier precedent. See Malone, supra note 117, at 1066-67.

In Sullivan v. Union Pacific Ry., 23 Fed. Cas. 368, 371 (D. Neb. 1874) the court 
found "that all the cases, English and American, rest upon the nisi prius decision, in 1808, of Lord Ellenborough in Baker v. Bolton." As described above, the court in rejecting that precedent as "not reasoned" was decidedly in the minority in the United States in the latter half of the nineteenth century.

126. 13 Scots L.T. 581 (1905). See Benjamin v. Nernberg, 102 Pa. Super. 471, 157 A. 10 (1931) where the court noted that "Although the game of golf has been played for many years by thousands of people, serious accidents to players resulting in litigation have been so few that there is little in the books to help the court." Id. at 10-11.

127. 13 Scots L.T. at 581-82. See also, Legal Questions Relating to Golfing and Golf Courses, 31 Scot. L.R. 194 (1915) (approving of the holding in Andrew).

128. See, e.g., Benjamin v. Nernberg, 102 Pa. Super 471, 157 A. 10, 11 (1931) ("The only case in point we have been able to find is that of Andrew v. Stevenson.... We see no reason ... why these principles should not apply to the instant case."); Strand v. Conner, 24 Cal. 584, 586 (Cal. D. Ct. App. 1962); Walsh v. Machlin, 128 Conn. 412, 23 A.2d 156, 157 (1941); Hoffman v. Polsky, 368 S.W.2d 376, 379 (Mo. 1965); Rogers v. Allis-Chamber Mfg., 153 Ohio St. 513, 92 N.E.2d 677, 682 (1950). See also Williams v. Woods, 260 Mich. 387, 244 N.W. 490, 491 (1932) (citing Legal Questions Relating to Golfing and Golf Courses, supra note 127).

129. See, e.g., Buck v. Clauson's Inn at Coonamesset, 211 N.E. $2 d 349$ (Mass. 1965).

130. See Epstein, Advance Notice of Alibi, 55 J. Crim. L., Criminology \& POL. SCI. 29 (1964).

131. See generally Everett, Discovery in Criminal Cases-In Search of a Standard, 1964 DUKE L.J. 477.

132. See Millar, The Modernation of Criminal Procedure, 11 J. CRIM. L. \& CRIMINOLOGY 344, 350 (1920) (characterizing alibi defenses as "one of the main avenues of escape of the guilty").

133. See Epstein, supra note 130 , at 29. Scots law now requires a criminal defendant to specify the alibi "place" at the time in question and requires special notice of other defenses such as insanity.

134. See Millar, supra note 132, at 351. See also Millar, The Statutory Notice of Alibi, 24 J. CRIM. L. \& CRIMINOLOGY 849 (1934).

135. Epstein, supra note 130, at 30 n.16. Representative state rules are collected in 6 J. Wigmore, EVidence in TRials at Common LaW sec. 1855(b) (rev. ed. Chadbourne 1976).

136. See Advisory Committee note, Fed. R. Crim P. 12.1. Rule 12.1 states in pertinent part:

(a) Notice by Defendant. Upon written demand of the attorney for the government stating the time, date and place at which the alleged offense was committed, the defendant shall serve ... upon the attorney for the government a written notice of the defendant's intention to offer a defense of alibi. Such notice by the defendant shall state the specific place or places at which the defendant claims to have been at the time of the alleged offense and the names and addresses of the witnesses upon whom the defendant intends to rely to establish such alibi.

137. Alicea v. Gagnon, 675 F.2d 913, 916 (7th Cir. 1982).

138. Cudahy Packing Co. v. Parramore, 263 U.S. 418, 425 (1923). The Court cited and quoted from George Anderson \& Co. v. Adamson, 50 Scot. L.R. 855 (1905).

139. See Sebo v. Libby, McNeil \& Libby, 216 Mich. 351, 185 N.W. 702, 703 (1921); Hinchuk v. Smith \& Co., 149 Minn. 1, 182 N.W. 622, 623 (1921); Prouse v. Industrial 
Commission, 194 P. $625,626-27$ (Cal. 1920); Carleton v. Foundry \& Machine Products Co., 199 Mich. 148, 165 N.W. 816, 817 (1917); In re Heitz, 218 N.Y. 148, 112 N.E. 750, 751 (1916); Spooner v. Detroit Saturday Night Co., 187 Mich. 125, 153 N.W. 657, 659 (1915). See also Reynolds v. Passaic Valley Sewage Com'rs, 20 N.J. Misc. 74, 24 A.2d 531, 534 (1942).

140. See Stump v. Norfolk Shipbuilding \& Dry Dock Corp., 187 Va. 932, 48 S.E.2d 209, 212 (1948); Kricinovich v. American Car \& Foundry Co., 192 Mich. 687, 159 N.W. 362, 364 (1916); Jendrus v. Detroit Steel Products Co., 178 Mich. 265, 144 N.W. 563,566 (1913).

141. Workmen's Compensation Act of 1897, 60 \& 61 Vict. ch. 37 (1897).

142. See, e.g., Pease, An English Workman's Remedies for Injuries Received in the Course of his Employment, at Common Law and By Statute, 15 Colum. L. Rev. 509 (1915).

143. There is some evidence that the holographic will in Virginia, authorized by a 1748 statute, was borrowed from Scots law. It may just as likely have come from English law, however. See J. McKnight, Legal Persistence and Change, 12-15 (unpublished manuscript).

144. See A. Chitnis, The Scottish Enlightenment 78 (1976); A. WAtson, supra note 62 , at 44 . See generally D. M. WALKER, A LEGAL. HistoRY OF SCOTLAND, vol. 1 (1988).

145. The early Roman influence was mostly of a procedural nature. See P. STEIN, Roman Law in Scotland in IUS ROMANUM MEDII AEVI 107 (1968); A. WATSON, supra note 62 , at $45-46$.

146. Id. at 46; Stein, The Influence of Roman Law on the Law of Scotland, 8 JURIDICAL REV. 205, 213-14 (1963).

147. Id; T. B. SMITH, A SHORT COMMENTARY ON THE LAW OF SCOTLAND 21 (1962);

B. SMith, Sources and Literature of SCOTS Law, Stair Soc., vol. 1, at 171.

148. See A. WATSON, supra note 62 , at $46-47$ quoting T. CRAIG, supra note 57 , at book I, tit. 2, sec. 8 (1655) ("But we in this kingdom are bound by the law of the Romans in so far as they are in harmony with the laws of nature and right reason.... Here there is an extreme scarcity of written laws and naturally we follow the Civil Law in most matters.") Although Ius Feudale was published in 1655, its author died in 1608. It is noteworthy that Ius Feudale was written in Latin. See also T. HoPE, MAJOR Practicks, book I, tit. 1, sec. 14 (1605-33) (Stair Society vols. 3-4, 1937-38). See also Stein, supra note 146, at 218-19 on Craig's use of Roman law.

149. The use of the term "institutes" in Scotland as well as in continental Europe derives directly from the Roman Emperor Justinian's famous Institutes. A widely accepted definition of "institutes" is "a book containing the elements of the Roman law." See Cairns, supra note 23, at 79-80.

150. WATSON, supra note 62 , at 48.

151. Specifically, Stair stated that Roman Law was "not acknowledged as a law binding for its authority, yet being, as a rule, followed by its equity." He acknowledged that Roman law was "common law" in the sense that it was common to many nations, including Scotland. Stair, Institutions of the Law of Scotland 87-88 (D. M. Walker ed. 1981). According to Stein "As far as possible Stair drew his law from the decisions of Scottish courts. Where such authority was lacking, he drew on the Roman law." Stein, supra note 146, at 220-21.

152. See T. B. SMITH, supra note 147 , at 23 ; Stein, supra note 146 , at $219-20$.

153. See Smith, Roman Law in The Sources and Literature of Scots Law 180-81 (Stair Society vol. 1 1936); T. B. SMrth, supra note 147, at 23. 
154. According to Professor Stein, "Many rules of Roman law were incorporated into Scots law in the eighteenth century, but the process was more self-conscious and deliberate than it had been in the seventeenth." Stein, supra note 146, at 221.

155. T. B. SMITH, supra note 147, at 23.

156. See Stein, supra note 146, at 243. One should not overlook the converse; Scots law has had an impact on English law, from the eighteenth century to the present. Although the English have typically not borrowed Scottish precedent, since Scots law regards precedent in a somewhat different manner, they have liberally appropriated Scottish legal principles. See L. Denning, supra note 119, at 5. See also A. D. GibB, LAW FROM OVER THE BORDER (1950).

157. The 1707 Union also produced a unified Parliament of Great Britain, empowered to make laws for all of the United Kingdom. The Parliament, both legislatively and judicially "was overwhelmingly English in composition and outlook." Thus, the Union, structurally through the advent of the new Parliament, paved the way for English law to have ever increasing importance and authority in Scotland. See Smith, English Influences on the Law of Scotland, in STUDIES CRITICAL AND COMPARATIVE 119 and generally at 116-36 (1962).

158. T. B. SMITH, supra note 147 , at 23-24.

159. Stein, supra note 146 , at 244.

160. See Smith, Strange Gods: The Crisis of Scots Law as a Civilian System in Studies CRITICal and Comparative 74-81 (1962). Roman law is a required course for admission to the Scottish Faculty of Advocates (the Scottish Bar).

161. For a helpful discussion on the sources of Scots law see T. B. SMITH, supra note 147, at 25-46. Resistance to English law remains robust in some circles. Perhaps the leading Scottish legal historian, Sir Thomas (T. B.) Smith, lameted in 1958 “. . . alas, since 1758, we in Scotland have gone a-whoring after some very strange gods." Smith, supra note 160, at 72. Compare Rodger, Report of the Scottish Law Commission on Antenatal Injury, 1974 JURIDICAL REv. 83 (favoring Roman law sources over English law) with Miller, The Use of Roman Law in Scotland: A Reply, 1975 JURIDICAL Rev. 64.

162. A. WATSON, supra note 62 , at 51 .

163. It is apparently easy to overstate the English common law influence on the American colonies. The law in the various colonies varied greatly; there were literally thirteen different legal systems. G. HASKINS, LAW AND AUTHORITY IN EARLY MASSACHUSETTS 6 (1960). English law and traditions were mixed with local law, custom and traditions in various combinations. See L. FrIEDMAN, note 12 supra, at 31 . However, few colonies explicitly adopted the common law. P. MiLLER, THE LIFE OF THE MIND IN AMERICA: From the Revolution to the Civil WaR 107 (1965).

164. T. B. Smith has called the period "the Dark Age of Scots Law." T. B. SMITH, supra note 147, at 16. See also A. WATSON, supra note 62 , at 51.

165. Prevailing pre-Revolutionary attitudes to the common law pointed to its acceptance as a body of principles to be liberally applied by the colonial courts. The colonial reception to British statutes was markedly more cautious and hostile. See $\mathbf{M}$. Horowitz, The Transformation of AMERICAN LAW, 1780-1860, at 4-9 (1977).

166. A. WATSON, supra note 62 , at 52 .

167. P. MiLleR, supra note 163 , at 109.

168. See notes 1 and 163, supra.

169. See, e.g., G. GiLmore, supra note 1, at 23; M. Horowitz, supra note 165, at 30 ("In 1820 the legal landscape in America bore only the faintest resemblance to what existed forty years earlier"); P. MILLER, supra note 163, at 124; Kent and Story were 
already prominent figures, Kent as Chief Justice of New York and then Chancellor, and Story as a Supreme Court Justice. Kent particularly has reverence for the common law. Id. at 123-24. The pinpointing of 1820 as significant for common law entrenchment appears surprisingly early, considering that the War of 1812, during which anti-English ardor was at its zenith, occurred only eight years earlier. However, as Gilmore points out, by 1820 America had its own body of law and literature and its own court system. Cases were regularly reported and American law books were beginning to appear. G. GILMORE, supra note 1, at 23.

170. See notes 27-33 and accompanying text, supra.

171. See P. Miller, supra note 163, at 123-27.

172. See note 157 , supra and accompanying text. See also note 156 , supra.

173. There are exceptions to this general rule even in places like New Zealand whose law has remained very English. Legitimization through the later marriage of the parents became law in New Zealand prior to England and was directly influenced by existing Scottish law. For a discussion of English law's "transplant" to New Zealand, see A. WATSON, supra note 62 , at 71-74.

174. See text accompanying note 20 supra.

175. See, e.g., W. BROCK, supra note 3, at 16.

176. Apparently, even the heroics of Scots such as Patrick Henry, John Paul Jones, and James Wilson failed to alter that perception. See, e.g., D. MEYERS, The Highland SCOTS OF NORTH CAROLINA, 1732-1776, at 131-62 (1957) (describing the largely Loyalist actions of the North Carolina Highland Scots). See generally notes 16-17, supra, and accompanying text. While Scottish emigrants were largely Loyalist, the Scotch-Irish were generally "patriots." The two groups opposed each other at the battle of King's Mountain in North Carolina. See J. Johnson, THE SCOTS AND SCOTCH-IRISH IN AMERICA 11 (1966). See also J. Leyburn, The SCOTCh-IRISH: A Social History 304-14 (1962) (concluding that, except for the Carolinas, "Scotch-Irish support for independence was generally ardent").

177. See note 15 supra and accompanying text.

178. The fact that Scots law has no code, unlike the continental civil law systems, may have contributed to the lack of perceived distinction from the common law.

179. See, e.g., M. HorowITz, supra note 165, at 4-5.

180. See, e.g., Stein, supra note 2 , at 407. 
, 